\title{
THE INFLUENCE OF BASALT MINERALS AS CEMENT SUBSTITUTION MATERIALS IN MORTAR
}

\author{
Muhammad $\operatorname{Amin}^{a}$, David Candra Birawidha ${ }^{a}$, Kunno Isnugroho ${ }^{a}$, \\ Yusup Hendronursito ${ }^{a}$, Slamet Sumardi ${ }^{a}$, Septa Ario ${ }^{b}$, Syafriadi $^{b}$, \\ Muhammad Al MuttaqiI ${ }^{a} *$ \\ ${ }^{a}$ Indonesian Institute of Sciences, Research Unit for Mineral Technology, Jl. Ir. Sutami Km. 15, Tanjung \\ Bintang, 35361, South Lampung, Indonesia \\ ${ }^{b}$ University of Lampung, Faculty of Mathematics and Science, Department of Physics, Jl. Prof. Dr. Soemantri \\ Brojonegoro No.1 Gedung Meneng, 35145, Lampung, Indonesia \\ * corresponding author: almuttaqiimuhammad@gmail.com
}

\begin{abstract}
This study was conducted to determine the effect of the concentration of basalt as a cement substitution material in mortar. Basalt was analysed by XRD and XRF. From the XRD results, the diffractogram shows the dominant phases, such as anorthite, augite, forsterite, and quartz or silicon oxide. $\mathrm{SiO}_{2}, \mathrm{Al}_{2} \mathrm{O}_{3}, \mathrm{Fe}_{2} \mathrm{O}_{3}$ are the main components in basalt, as can be seen from the XRF. With the concentration at $5 \%$ of the basalt before the calcination, the optimum compressive strength of the OPC and PCC cement mortar was obtained. The highest compressive strength of the OPC cement mortar was $24.97 \mathrm{MPa}$ with a porosity of $2.4 \%$ and absorption of $1.29 \%$. Furthermore, the highest compressive strength of the PCC cement mortar was $22.55 \mathrm{MPa}$ with a porosity of $4.8 \%$ and absorption of $2.52 \%$. This result indicates that the substitution of composite cement with a basalt with a concentration of $5 \%$ can increase the compressive strength of the mortar.
\end{abstract}

Keywords: Basalt, OPC, PCC, mortar, compressive strength.

\section{INTRODUCTION}

Indonesia is a country that has abundant metallic and non-metallic mineral resources. One of the nonmetallic mineral resources is basalt rock. Based on the data from the Ministry of Energy and Mineral Resources Center in 2014, Indonesia has 6,282,661,980 tons of non-metallic basalt mineral resources. Meanwhile, according to the Lampung Mining and Energy Department, there are $318,480,000$ tons of basal rock reserves [1].

Basalt is a one type of igneous rock formed by freezing magma on the surface of the earth, alkaline and grey in colour [2, 3. The composition of basalts, with materials such as $\mathrm{SiO}_{2}, \mathrm{Al}_{2} \mathrm{O}_{3}$ and $\mathrm{Fe}_{2} \mathrm{O}_{3}$ comprising more than $70 \%$, makes basalt a potential material that can be promoted into a cement or pozzolan substitution [4. Pozzolan is a material that does not have properties like cement, but compounds, such as silica or silica-alumina, can react with $\mathrm{Ca}(\mathrm{OH})_{2}$ and form compounds that have properties similar to cement (CSH) [5]. Generally, Pozzolan was used as a substitute of cement in mortars and concrete. The use of pozzolan as a cement substitute material can increase the porosity of the paste in the mixture of mortar consisting of cement, sand, water and other additives [6].

Dobiszewska et al., [7] used basalt powder with different variations as a substitution in materials. It was shown that $8 \%$ of the weight concentration is optimal with respect to compressive and flexural strength.
Abdelaziz et al., [8] used basalt powder and limestone in a mortar as a substitute of Portland cement and it exhibited the greatest compressive strength at a concentration of $12 \%$. Basalt powder can be used as a cement replacement material that is measured in accordance with specifications related to natural pozzolan based on ASTM C618 requirements, such as chemical components and physical properties 9 . Pourkhorshidi et al., 10 stated that the minimum concentration of $\mathrm{SiO}_{2}+\mathrm{Al}_{2} \mathrm{O}_{3}+\mathrm{Fe}_{2} \mathrm{O}_{3}$ is $70 \%$ for the pozzolan activity, fineness retained in filter no. $325(45 \mu \mathrm{m})$ (wet sieved at $45 \mu \mathrm{m}$ sieves) maximum $34 \%$ and pozzolanic activity index at least $75 \%$.

In this research, basalt powder before and after the calcination was used as a cement substitution material in a mortar. It was tested for compressive strength, porosity, and absorption after 28-days.

\section{MAterials AND METHOdS}

\subsection{MATERIALS}

Basalt stone was obtained from Mataram Baru, East Lampung, Sumatera. Portland cement type I (Ordinary Portland Cement) from Semen Padang Indonesia. Portland Cement Composite (PCC) type I from Holcim, Indonesia, and sand beach from Maringgai, East Lampung.

\subsection{BASALT PREPARATION}

Basalt stone was crushed by jaw crusher and grinded in the ball mill for $4 \mathrm{~h}$. Then, the basalt powder was 
sifted using mesh no. 325. Basalt powder was calcined using electric furnace panels at $900^{\circ} \mathrm{C}$ for $1 \mathrm{~h}$.

\subsection{MORTAR PREPARATION}

The production process of mortars begins with mixing all materials having different compositions. The composition weight ratio of cement:sand was 1:2.75 and the weight concentration of the basalt powder was 0 , $5,10,15$, and $20 \%$. The water to cement ratio was equal to $0.4-0.50$. After that, the mixture was stirred until it was homogenous and put into a $5 \times 5 \times 5 \mathrm{~cm}$ cube mould and dried for $24 \mathrm{~h}$. Then, the mortar was soaked for 28 days and samples were tested for compressive strength and physical properties.

\subsection{SAMPLE CHARACTERIZATION}

The crystallinity and phase of basalt stone were measured by X-Ray Diffraction (XRD: Panalytical Xpert 3 Powder XRD) with a $\mathrm{Cu}-\mathrm{K} \alpha$ as a source of X-ray operating at $40 \mathrm{kV}$ and $30 \mathrm{~mA}$. Samples were scanned in the range $2 \theta$ of $0-80^{\circ}$. The chemical composition of basalt stone was characterized by X-Ray Fluorescence (XRF Epsilon 4 XRF Spectrometer from Malvern Panalytical) operating at $50 \mathrm{kV}$ and $3 \mathrm{~mA}$. The compressive strength testing of OPC, PCC, and mortar was analysed by the Farrance Wykeham Machine (Model 55104 with capacity $1500 \mathrm{kN}$ ). The testing of beach sand, such as water content, gradation, specific gravity, sludge levels, and absorption, was conducted to characterize the used material properly. The water content was tested with ASTM D-2216 and the gradation with ASTM C-33. For testing the specific gravity, a pycnometer, according to ASTM D-854, was used. The sludge levels were tested with SNI 03-2461-2002, the absorption with SNI 1970-2008.

\section{Results And Discussion}

\subsection{The Characterization OF BASAlt STONE}

The composition of basalt stone from Mataram Baru, East Lampung, Sumatera is presented in Table 1. Table 1 shows the basalt before and after the calcination, which has a total content of $\mathrm{SiO}_{2}+\mathrm{Al}_{2} \mathrm{O}_{3}+\mathrm{Fe}_{2} \mathrm{O}_{3}$ of $82.155 \%$ and $82.190 \%$. Based on ASTM C618, basalt fulfills chemical requirements as a cement or pozzolan substitution. Generally, the content of pozzolan with a percentage of total gravity of $\mathrm{SiO}_{2}, \mathrm{Al}_{2} \mathrm{O}_{3}$, and $\mathrm{Fe}_{2} \mathrm{O}_{3}$ of $50 \%$ produces good pozzolanic materials and it can be used as a cement substitution material [11.

The XRD patterns of basalt before and after the calcination are presented in Figure 1. In Figure 1a. the diffractogram of the basalt before the calcination is dominated by peaks of anorthite, augite, forsterite, quartz. After the calcination in Figure 1b the peaks of anorthite, augite, forsterite, and silicon oxide dominated. Generally, this phase consists of compounds, such as calcium, silica, alumina, iron oxide and magnesium. In addition, the calcination does not significantly influence the phase formed in the sample. The results of the analysis of sand beach are presented in Table 2. The results showed that the standard is sufficient as a fine aggregate in the mortar.

\subsection{THE EFFECT OF BASALT AS CEMENT SUBSTITUTION MATERIAL IN MORTAR}

The compressive strength testing was carried out on mortar specimens with dimensions of $5 \times 5 \times 5 \mathrm{~cm}$. The purpose of this test was to get the value of the mortar's compressive strength and determine the quality of the mortar. The results of the compressive strength testing are shown in Figure 2 and Figure 3 The compressive strength of Ordinary Portland Cement (OPC) was 19.50 MPa. In Figure 2 the values of the compressive strength of the OPC at concentrations of 5,15 , and $20 \%$ with basalt powder before the calcination are $24.97,21.03$, and $22.37 \mathrm{MPa}$, respectively, while the value of the compressive strength at a concentration of $10 \%$ reached $17.89 \mathrm{MPa}$. This is because the index of the pozzolan from basalt is still low compared to a standard value. With the basalt powder, after calcination, the value of the compressive strength of the OPC at concentrations of 5 and $20 \%$ are 20.85 and 24.16 MPa, respectively. In addition, with concentrations of 10 and $15 \%$, the strength only reached 15.83 and $15.92 \mathrm{MPa}$, respectively. This result indicates that the heavy concentration of basalt powder after calcination can negatively affect the compressive strength of the mortar.

The standard compressive strength of Portland Cement Composite (PCC) was 13.95 MPa. In Figure 3 the values of the compressive strength of the PCC at concentrations of 5 and $10 \%$ with basalt powder before the calcination are 22.55 and $19.15 \mathrm{MPa}$, respectively. In addition, with concentrations of 15 and $20 \%$, it only reached $11.98 \mathrm{MPa}$ and $9.02 \mathrm{MPa}$, respectively. With basalt powder after calcination at concentrations of $5,10,15$, and $20 \%$, the value of the compressive strength of the PCC were 21.11, 17.62, 10.36, and 9.92 MPa, respectively. This result indicates that the substitution of cement with basalt concentration of $5 \%$ can increase the strength due to a reduction of the cement content in the mortar [12, 13].

The value of the compressive strength is influenced by the density of the mortar. The addition of the basalt into the mortar increases the compressive strength as a consequence of the density increment. As shown in Table 3, the cement matrix such as pozzolan (based on ASTM C618) consists of $\mathrm{SiO}_{2}+\mathrm{Al}_{2} \mathrm{O}_{3}+\mathrm{Fe}_{2} \mathrm{O}_{3}$ by more than $70 \%$, in our case, the amount before and after the calcination was $82.155 \%$ and $82.190 \%$, respectively [14. Furthermore, the mortar with the basalt after the calcination showed a lower compressive strength than before the calcination. This is because high temperatures in pozzolan materials can affect the pore volume in the mixture so that the compressive strength decreases [15]. The water to cement ratio is very influential on the level of dryness of the mortar. If the ratio is higher, the 


\begin{tabular}{lccccc}
\hline \multirow{2}{*}{ No } & Sand & Water & OPC cement & \multicolumn{2}{c}{ Basalt powder } \\
\cline { 5 - 6 } & $(\mathrm{gr})$ & $(\mathrm{mL})$ & $(\mathrm{gr})$ & Before calcination & After calcination \\
\hline 1. & 688 & 121 & 250 & - & - \\
2. & 688 & 121 & 237.5 & 12.5 & - \\
3. & 688 & 121 & 225 & 25 & - \\
4. & 688 & 121 & 212.5 & 37.5 & - \\
5. & 688 & 121 & 200 & 50 & - \\
6. & 688 & 121 & 237.5 & - & 2.5 \\
7. & 688 & 121 & 225 & - & 37.5 \\
8. & 688 & 121 & 212.5 & - & 50 \\
9. & 688 & 121 & 200 & - & \\
\hline
\end{tabular}

TABLE 1. Mortar mixture proportions (gr) with OPC cement.

\begin{tabular}{lccccc}
\hline \multirow{2}{*}{ No } & Sand & Water & PCC cement & \multicolumn{2}{c}{ Basalt powder } \\
\cline { 5 - 6 } & $(\mathrm{gr})$ & $(\mathrm{mL})$ & $(\mathrm{gr})$ & Before calcination & After calcination \\
\hline 1. & 688 & 121 & 250 & - & - \\
2. & 688 & 121 & 237.5 & 12.5 & - \\
3. & 688 & 121 & 225 & 25 & - \\
4. & 688 & 121 & 212.5 & 37.5 & - \\
5. & 688 & 121 & 200 & 50 & - \\
6. & 688 & 121 & 237.5 & - & 25 \\
7. & 688 & 121 & 225 & - & 37.5 \\
8. & 688 & 121 & 212.5 & - & 50 \\
9. & 688 & 121 & 200 & - & \\
\hline
\end{tabular}

TABLE 2. Mortar mixture proportions (gr) with PCC cement.

\begin{tabular}{lcc}
\hline \multirow{2}{*}{ Compounds } & \multicolumn{2}{c}{ Percentage (\%) } \\
\cline { 2 - 3 } & Before calcination & After calcination \\
\hline $\mathrm{SiO}_{2}$ & 50.729 & 50.303 \\
$\mathrm{Al}_{2} \mathrm{O}_{3}$ & 19.337 & 19.417 \\
$\mathrm{Fe}_{2} \mathrm{O}_{3}$ & 12.109 & 12.470 \\
$\mathrm{CaO}$ & 10.358 & 10.300 \\
$\mathrm{MgO}$ & 4.387 & 4.418 \\
$\mathrm{TiO}$ & 1.378 & 1.368 \\
$\mathrm{~K}_{2} \mathrm{O}$ & 0.654 & 0.676 \\
$\mathrm{P}_{2} \mathrm{O}_{5}$ & 0.529 & 0.519 \\
$\mathrm{MnO}_{\mathrm{SiO}}+\mathrm{Al}_{2} \mathrm{O}_{3}+\mathrm{Fe}_{2} \mathrm{O}_{3}$ & 0.202 & 0.213 \\
& 82.175 & 82.19 \\
\hline
\end{tabular}

TABLE 3. The composition of basalt stone. 


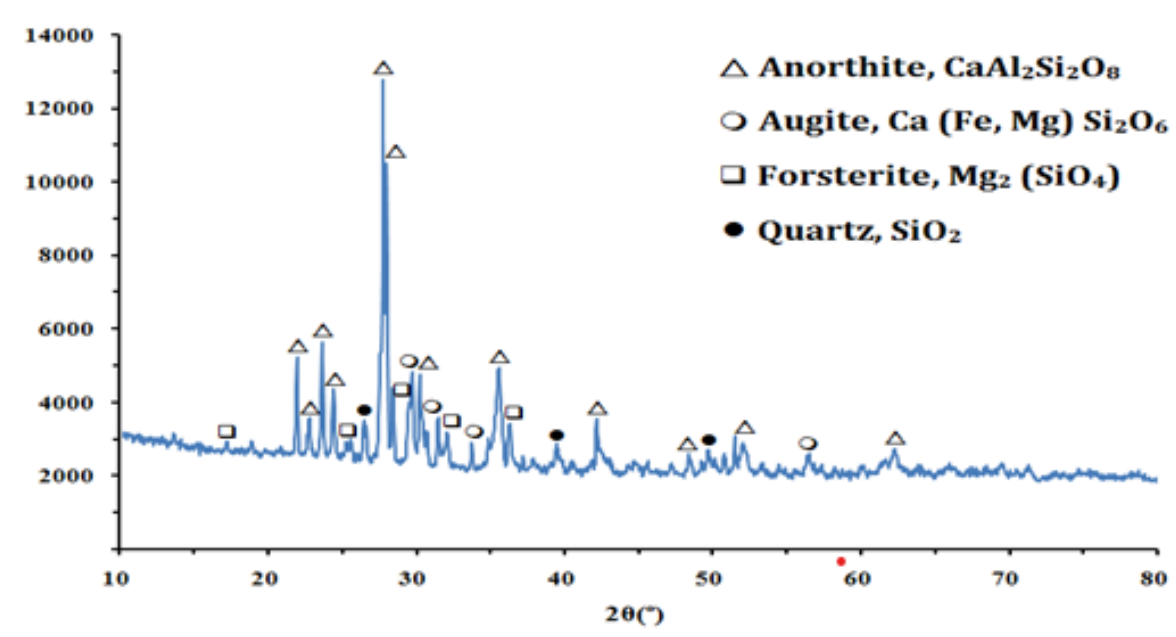

(A).

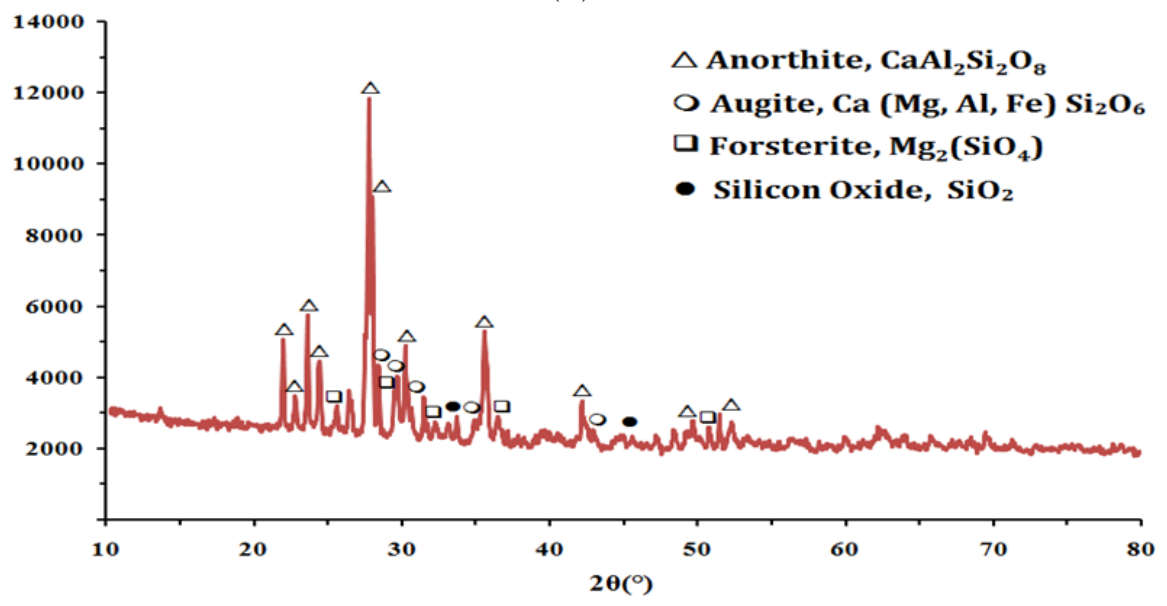

(B).

FiguRE 1. XRD diffractogram pattern of basalt samples before and after calcination.

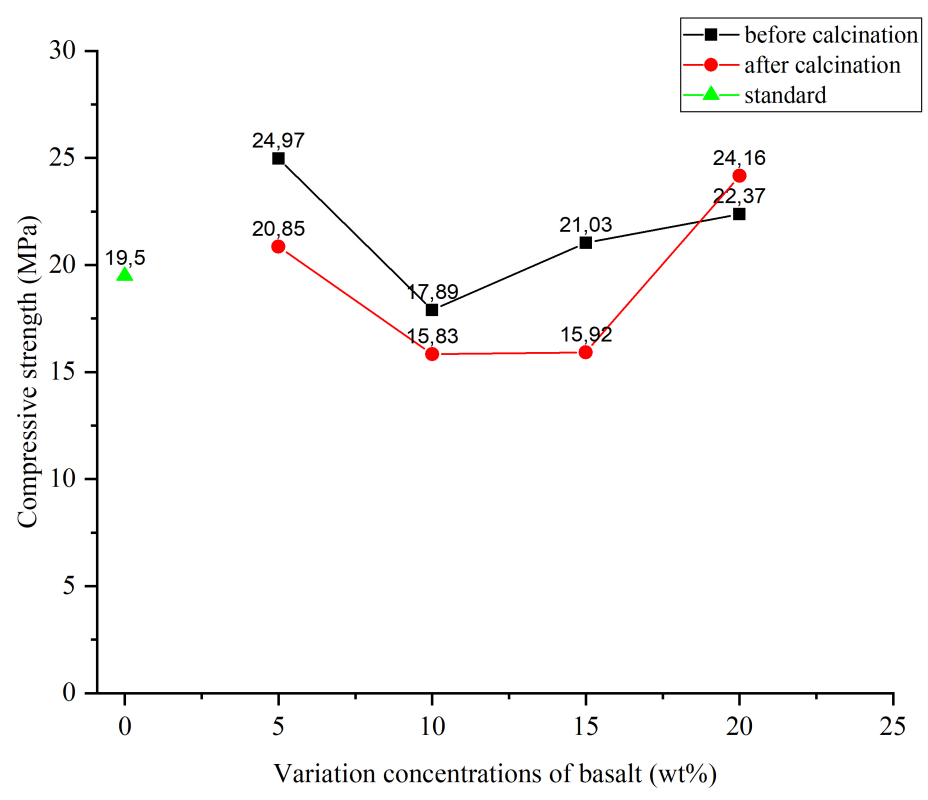

FIgURE 2. Compressive strength of OPC cement mortar with variations concentration. 


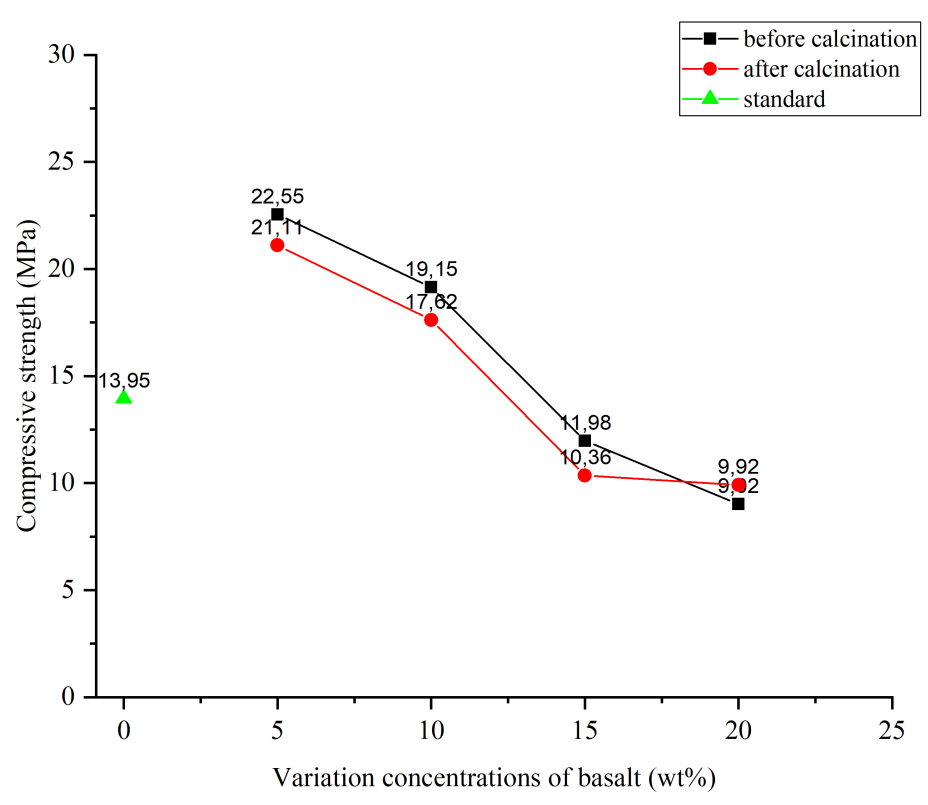

FIGURE 3. Compressive strength of OPC cement mortar with variations concentration.

mortar is more dilute and dries for longer, therefore, it affects the compressive strength of the mortar.

The compressive strength of the mortar with the substitution of the basalt has a higher compressive strength due to a good pozzolan reaction. When the silica-containing pozzolan material is added during the hydration of Portland cement, it reacts with calcium hydroxide $\mathrm{Ca}(\mathrm{OH})_{2}$ to provide additional Calcium Silicate Hydrate $(\mathrm{CSH})$, which is a major component in the cement hydration. Gradually, the addition of calcium silicate hydrate formed binds and fills the space and thus provides a better impermeability, durability and strength [16]. The pozzolanic reaction that occurs during hydration is:

$$
\mathrm{Ca}(\mathrm{OH})_{2}+\mathrm{SiO}_{2} \longrightarrow \mathrm{C}-\mathrm{S}-\mathrm{H}
$$

Basalt can react with $\mathrm{Ca}(\mathrm{OH})_{2}$ during the hydration reaction and form calcium silicate hydrate $(\mathrm{CSH})$. It reduces the pores of the product and makes the microstructure of the material more uniform, increases density, compressive strength, and durability [9]. In addition, the size of the basalt powder $(45 \mu \mathrm{m})$ causes a larger surface area, which increases the reactivity of pozzolan. The smaller size causes the basalt to be dispersed into the mixture of cement in the mortar and makes the cement more homogeneous. This powder will fill the voids that exist and make the structure more solid and thus increases the compressive strength [17].

\subsection{Porosity AND ABSORPTION PROPERTIES OF OPC AND PCC CEMENT MORTAR}

Porosity and absorption properties of the OPC and PCC cement mortar with various concentrations of basalt are shown in Figure 4. The porosity and absorption of the OPC cement mortar are 3.2 and $1.73 \%$, respectively. In Figure $4 \mathrm{a}$ the concentrations of basalt, before the calcination, of 5,10,15 and $20 \%$ are shown, having a porosity of $2.4,4.0,3.2$ and $2.4 \%$, with an absorption of 1.29, 2.13, 1.69 and $1.29 \%$, respectively. In Figure $4 \mathrm{~b}$ the concentrations of basalt, after the calcination, of 5, 10, 15 and $20 \%$, having a porosity of $3.2,4.8,4.8$ and $2.4 \%$, with an absorption of 1.70 , $2.58,2.54$ and $1.30 \%$, respectively. The porosity and absorption of the PCC cement mortar are 8.0 and $4.24 \%$, respectively. In Figure 4c the concentrations of basalt, before the calcination, of 5, 10, 15 and $20 \%$, having a porosity of $4.8,4.8,8.8$ and 11.2 , with an absorption of $2.52,2.56,4.85$ and $5.98 \%$, respectively. In Figure $4 \mathrm{~d}$, the concentrations of basalt, after the calcination, of 5, 10, 15 and $20 \%$, having a porosity of $4.8,5.6,8.8$ and $10.4 \%$, with an absorption of 2.50 , $3.06,4.93$ and $5.58 \%$, respectively.

Porosity is reduced because large pores in the mortar are filled up with basalt. This result improved mechanical properties of mortar [18. Furthermore, the reduction of porosity is due to the fewer pores that are connected so that compressive strength will be higher and the absorption of water will be smaller [19. These results indicate that basalt can reduce the porosity and absorption of the PCC and OPC cement mortar. The secondary reaction formation of calcium silicate hydrate (CSH) produced from the pozzolan reaction between the basalt and cement in the mortar can increase the bond between the paste and aggregate so it can reduce the porosity and capillaries in the mortar. The decrease in porosity and capillary shows that the 


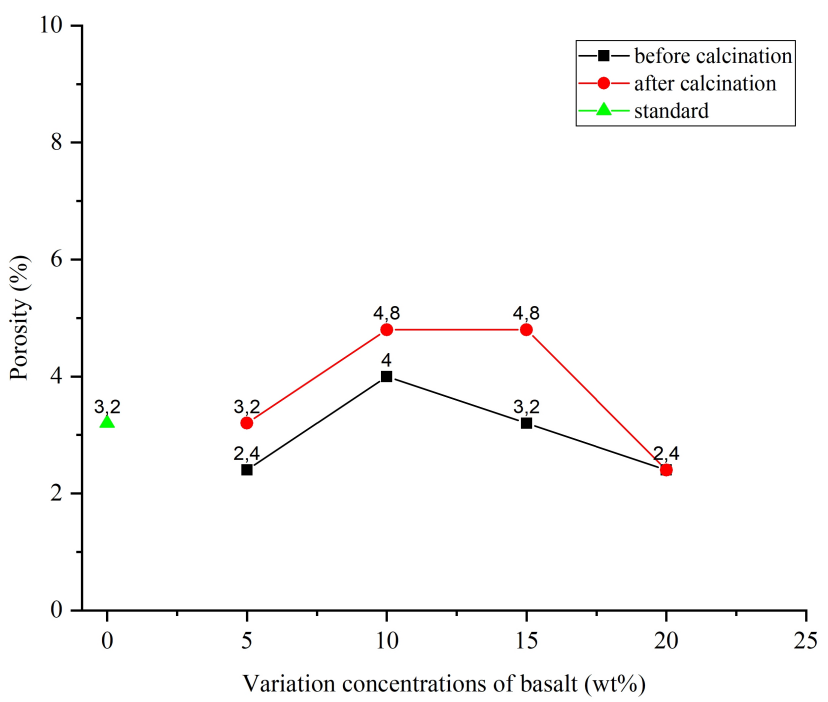

(A).

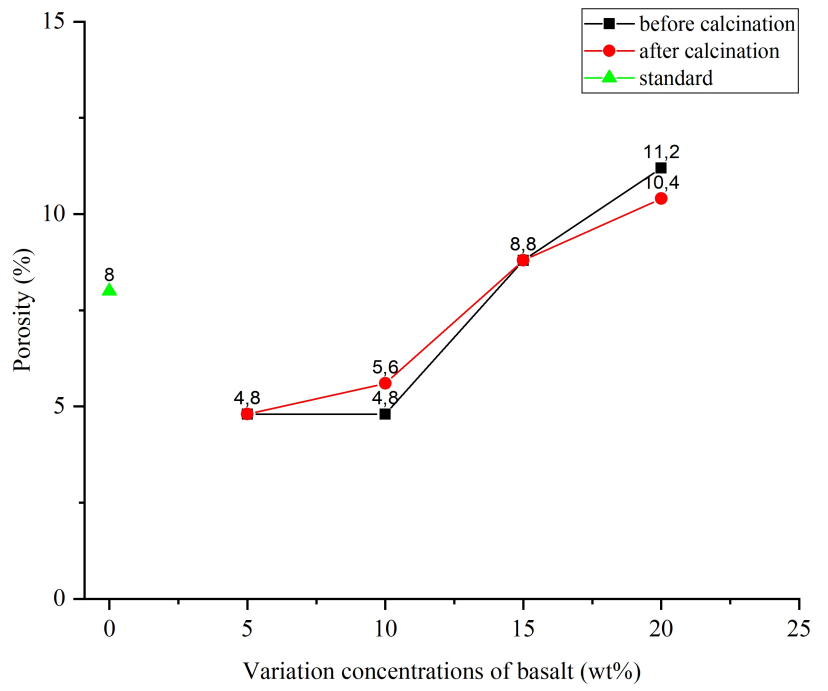

(C).

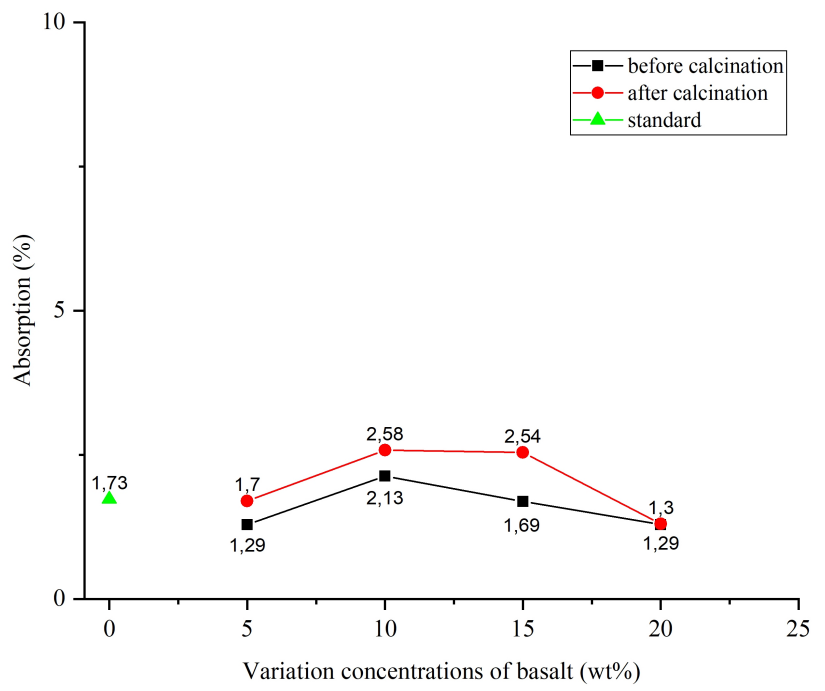

(B).

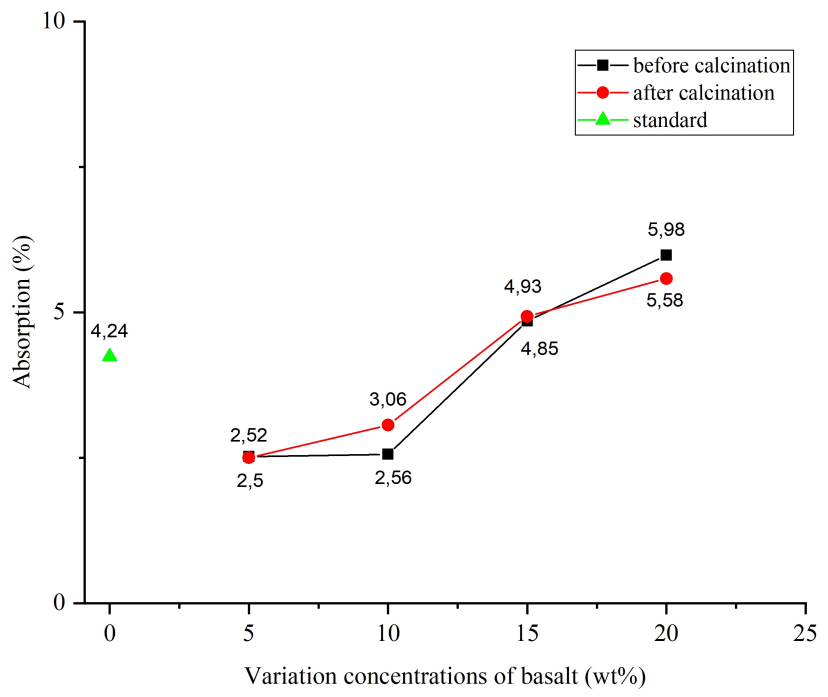

(D).

FiguRE 4. The porosity and absorption properties of OPC cement mortar (a and b) and PCC cement mortar (c and d) with variation concentration of basalt.

\begin{tabular}{ccccc}
\hline No. & Testing & Results & Standard & Information \\
\hline 1. & Water content & $0.3 \%$ & - & According to humidity \\
2. & Gradation & 2.3 & $2.2-3.2$ & Qualify \\
3. & Specific gravity & $2.55 \mathrm{gr} / \mathrm{cm}^{3}$ & $2.4-2.9$ & Qualify \\
4. & Sludge levels & $1.3 \%$ & $\leq 5 \%$ & Qualify \\
5. & Absorption & $3.1 \%$ & $\leq 13.27 \%$ & Qualify \\
\hline
\end{tabular}

TABLE 4. The results of analysis of sand testing. 
smaller pores are responsible for the good mechanical performance 20 .

\section{Conclusions}

This paper has demonstrated the potential of using basalt from Mataram Baru, East Lampung, Sumatera. It was found that the compressive strength of the OPC cement mortar and the PCC cement mortar with basalt at a concentration of $5 \%$ before a calcination was 24.97 and $22.55 \mathrm{MPa}$, respectively. Furthermore, the mortar with the basalt showed a lower compressive strength after the calcination than before the it. This is because high temperatures in pozzolan materials can affect the pore volume in the mixture so that the compressive strength decreases.

\section{ACKNOWLEDGEMENTS}

The authors would like to thank Research Unit for Mineral Technology- Indonesian Institute of Sciences for the research grant supporting this work.

\section{REFERENCES}

[1] M. Amin, Suharto. Manufacture of environmentally friendly geopolymer cement made from basal mineral raw material to reach lampung prosperous. Development Journal 05(01):30-45, 2017.

[2] D. Noor. Introduction to Geology. Pakuan University Press, Bogor, 2012.

[3] S. U. Soetoto. Basic Geology. Wave Publisher, Yogyakarta, 2013.

[4] M. Saraya. Study the pozzolanic activity of fresh basalt. Journal of Materials Science and Engineering 1:790-800, 2011.

[5] F. Massazza. LEA's Chemistry of Cement and Concrete, chap. Pozzolana and Pozzolanic Cements, pp. 471-602. Butterworth-Heinemann, Oxford, 1988. DOI:10.1016/B978-075066256-7/50022-9

[6] N. Mohamed Sutan, S. Hamdan, H. Sobuz, et al. Porosity and strength of pozzolan modified cement systems. Concrete Research Letters 2(4):326-335, 2012.

[7] M. Dobiszewska, A. Beycioğlu. Investigating the influence of waste basalt powder on selected properties of cement paste and mortar. IOP Conference Series: Materials Science and Engineering 245:1-10, 2017. DOI:10.1088/1757-899x/245/2/022027.

[8] M. A. Abdelaziz, S. A. El-Aleem, W. M. Menshawy. Effect of fine materials in limestone and basalt on the properties of portland cement pastes and mortars. International Journal of Engineering Research \& Technology 3(6):1038-1056, 2014.
[9] L. Laibao, Z. Yunsheng, Z. Wenhua, et al. Investigating the influence of basalt as mineral admixture on hydration and microstructure formation mechanism of cement. Construction and Building Materials 48:434440, 2013. DOI:10.1016/j.conbuildmat.2013.07.021.

[10] A. Pourkhorshidi, M. Najimi, T. Parhizkar, et al. Applicability of the standard specifications of ASTM C618 for evaluation of natural pozzolans. Cement and Concrete Composites 32(10):794 - 800, 2010. DOI:10.1016/j.cemconcomp.2010.08.007.

[11] A. A. Al-Rawas, A. W. Hago, T. C. Corcoran, K. M. Al-Ghafri. Properties of Omani artificial pozzolana (sarooj). Applied Clay Science 13(4):275 - 292, 1998. DOI:10.1016/S0169-1317(98)00029-5

[12] V. Kmecová, Z. Stefunková. Effect of basalt powder on workability and initial strength of cement mortar. Journal of Civil Engineering and Architecture Research 1(4):260 - 267, 2014.

[13] S. Unčík, V. Kmecová. The effect of basalt powder on the properties of cement composites. Procedia Engineering 65:51 - 56, 2013. DOI:10.1016/j.proeng.2013.09.010

[14] L. Opoczky. Progress of the particle size distribution during the intergrinding of a clinker-limestone mixture. Zement-Kalk-Gips 45:648 - 651, 1992.

[15] A. A. Ramezanianpour. Cement Replacement Materials: Properties, Durability, Sustainability. Springer, Verlag Berlin Heidelberg, 2014.

[16] S. K. Duggal. Building Material. New Age International (P) Limited, Publishers, New Delhi, 2008.

[17] P. Chindaprasirt, C. Jaturapitakkul, T. Sinsiri. Effect of fly ash fineness on microstructure of blended cement paste. Construction and Building Materials 21(7):15341541, 2007. DOI:10.1016/j.conbuildmat.2005.12.024.

[18] P. Lawrence, M. Cyr, E. Ringot. Mineral admixtures in mortars effect of type, amount and fineness of fine constituents on compressive strength. Cement and Concrete Research 35(6):1092 - 1105, 2005. DOI:10.1016/j.cemconres.2004.07.004

[19] H. Zhang. Building Materials in Civil Engineering. Woodhead Publishing Limited and Science Press, Cambridge, 2011.

[20] Y. Senhadji, G. Escadeillas, H. Khelafi, et al. Evaluation of natural pozzolan for use as supplementary cementitious material. European Journal of Environmental and Civil Engineering 16(1):77 - 96, 2012. DOI:10.1080/19648189.2012.667692 